\title{
Physical and psychological violence in Jamaica's health sector
}

\author{
Maria Jackson ${ }^{1}$ and Deanna Ashley ${ }^{2}$
}

Suggested citation Jackson M, Ashley D. Physical and psychological violence in Jamaica's health sector. Rev Panam Salud Publica. 2005;18(2):114-21.

ABSTRACT Objective. To determine the prevalence of experiences with physical violence and psychological violence that health staff have had in the workplace in Jamaica, and to identify factors associated with those experiences of violence.

Design and Methods. A total of 832 health staff answered the standardized questionnaire that was used in this cross-sectional study. Sampling was done at public facilities, including specialist, tertiary, and secondary hospitals in the Kingston Metropolitan Area; general hospitals in the rural parishes; and primary care centers in urban and rural areas. Sampling was also done in private hospitals and private medical centers.

Results. Psychological violence was more prevalent than was physical violence. Verbal abuse had been experienced in the preceding year by $38.6 \%$ of the questionnaire respondents, bullying was reported by $12.4 \%$, and physical violence was reported by $7.7 \%$. In multivariate analyses there was a lower risk of physical violence for health staff who were 55 years or older, worked during the night, or worked mostly with mentally disabled patients, geriatric patients, or HIV/AIDS patients. Staff members working mostly with psychiatric patients faced a higher risk of physical assaults than did other health staff. Of the various health occupations, nurses were the ones most likely to be verbally abused. In terms of age ranges, bullying was more commonly experienced by health staff 40-54 years old.

Conclusions. Violence in the health sector workplace in Jamaica is an occupational hazard that is of public health concern. Evaluation of the environment that creates risks for violence is necessary to guide the formulation of meaningful interventions for the country.

Key words Workplace; health personnel; violence; wounds and injuries; stress, psychological; occupational health; Jamaica.

Violence destroys lives and undermines health, and it occurs in varying degrees in all societies, and in many

\footnotetext{
1 University of the West Indies, Department of Community Health \& Psychiatry, Mona, Kingston, Jamaica. Send correspondence to: Maria Jackson, Department of Community Health \& Psychiatry, University of the West Indies, Mona, Kingston 7, Jamaica; telephone: (876) 927-1752 or (876) 9272476; fax: (876) 977-6346; e-mail: maria.jackson @uwimona.edu.jm

2 Jamaica, Ministry of Health, Kingston, Jamaica.
}

different settings within each society (1). In Jamaica, violence is a major cause of morbidity and mortality (2). Media reports in Jamaica on violence in the workplace, and within the health sector in particular, have focused on experiences of physical violence perpetrated by members of the public. However, there is little scientifically documented information on the prevalence of workplace violence in the country.
Violence at work includes not only observable physical acts but also psychological behaviors. Victims are subjected to bullying, threats, intimidation, sexual harassment, and other forms of psychological violence (3). Violence in the workplace can cause both immediate and long-term disruption to interpersonal relationships and to the working environment in general. The costs of violence are varied and 
range widely, including: (1) direct costs stemming from such things as accidents, illness, disability and death, absenteeism, and attrition of staff; (2) indirect costs, such as reduced work performance; and (3) intangible costs, including damage to the image of an organization, decreased motivation and morale, lower levels of creativity, and the creation of an environment that is less conducive to work.

In 2000 the International Labour Office (ILO), International Council of Nurses (ICN), World Health Organization (WHO), and Public Services International (PSI) launched a joint initiative to develop policies and practical programs for the prevention and elimination of violence in the health sector. With the long-term goal of developing or modifying country-specific policies and strategies, the ILO/ICN/WHO/ PSI effort sought to determine the magnitude and characteristics of physical and psychological violence in the health sector in Brazil, Bulgaria, Jamaica, Lebanon, Portugal, South Africa, and Thailand (3). (Australia conducted an independent investigation of violence in its health sector.)

In this report on the findings in Jamaica, we describe the prevalence and nature of health staff's experiences of violence, and we identify risk and protective factors for exposure to physical violence and to psychological violence of verbal abuse and bullying.

\section{MATERIALS AND METHODS}

\section{Definition of violence}

For this investigation, we defined workplace violence as "incidents where staff are abused, threatened, or assaulted in circumstances related to their work (including commuting to and from work), involving an explicit or implicit challenge to their safety, wellbeing, or health."

The definition covers a broad range of outcomes, including (1) physical violence and (2) psychological violence, expressed as verbal abuse, bullying, sexual harassment, or racial harass- ment. In this study we did not attempt to estimate the extent to which individuals may have experienced multiple forms of violence, even though it is not unusual for some persons to have experienced more than one type of violence.

\section{Sampling}

Our Jamaica investigation adopted the ILO/ICN/WHO/PSI initiative's guidelines. We conducted our study in urban and rural areas of the country, using a multistage sampling technique. The sample represented the range of health care settings, professional groups, and hierarchy levels in all types of health facilities and work settings in the public sector and the private sector.

A comprehensive listing of public health facilities and private health facilities in the Kingston Metropolitan Area (KMA), other urban areas, and rural areas was obtained from the
Ministry of Health $(\mathrm{MOH})$ (see Table 1 , which provides information on the public health facilities in Jamaica). That $\mathrm{MOH}$ listing served as the sampling frame for the study. The health facilities were stratified into three categories, with each level divided into groups of strata based on: (1) size of the health care facility; (2) level of care provided, including: (a) a leading referral hospital in a major city, (b) regional and district hospitals, (c) health centers, (d) long-term (rehabilitation) care facilities, and (e) private health care offices; and (3) location (rural or urban).

From the KMA, health staff at one Type A public general hospital, one Type B public general hospital, and all the specialist hospitals were recruited for enrollment in the study. Health workers at two Type $\mathrm{C}$ hospitals in rural parishes provided information for general hospitals. Twenty health centers (Types 1-5) in urban and rural areas were randomly selected and provided information on primary health

\section{TABLE 1. Types and numbers of public health facilities in Jamaica, 2002}

\begin{tabular}{|c|c|}
\hline Facility type/number & Services provided \\
\hline \multicolumn{2}{|l|}{ Hospital (secondary health care facility): } \\
\hline Type A (tertiary level hospital, 2) & $\begin{array}{l}\text { Multidisciplinary referral hospital. Receives referrals } \\
\text { from Type B and Type C hospitals. Offers a wide } \\
\text { range of medical, surgical, and pediatric specialist } \\
\text { services. }\end{array}$ \\
\hline Type B (secondary level hospital, 5) & $\begin{array}{l}\text { Regional referral hospital. Services include medicine, } \\
\text { surgery, obstetrics, gynecology, and mental health. }\end{array}$ \\
\hline Type C (basic general hospital, 10) & $\begin{array}{l}\text { General hospital. Provides basic medical and } \\
\text { surgical services. }\end{array}$ \\
\hline Specialist (5) & $\begin{array}{l}\text { Specialist referral facility that includes services for } \\
\text { terminally ill, mental illness, and physical } \\
\text { rehabilitation. Located in the Kingston Metropolitan } \\
\text { Area. }\end{array}$ \\
\hline \multicolumn{2}{|l|}{ Health center (primary health care facility) } \\
\hline Type $1(160)$ & $\begin{array}{l}\text { Maternal and child health, nutrition, and family } \\
\text { planning services. }\end{array}$ \\
\hline Type 2 (85) & Type 1 services plus selected curative services. \\
\hline Type 3 (62) & $\begin{array}{l}\text { Type } 1 \text { and Type } 2 \text { services plus full range of primary } \\
\text { care preventive and curative services. }\end{array}$ \\
\hline Type 4 (9) & Similar to Type 3 , in rural parish capitals. \\
\hline Type 5 (4) & $\begin{array}{l}\text { Wide range of services, including some specialties; } \\
\text { only in large urban areas. }\end{array}$ \\
\hline
\end{tabular}


care facilities. Two private hospitals and two private medical centers (groups of private health care professionals) were also selected for study.

A listing of personnel categorized according to professional groups was obtained from each institution to be studied. Among health facilities with large numbers of staff in the occupational group, a sample of at least $10 \%$ was randomly selected from each group. Where a facility was small or had fewer than 10 persons in an occupational group, all listed employees were included in the sample.

\section{Data collection}

For our Jamaica research the standardized questionnaire that had been developed by the ILO/ICN/WHO/PSI initiative was pretested at a health facility that was not included in our main study. (A copy of the final questionnaire used is available from the authors.) The information collected included demographic and workplace data. Health staff were asked to report on their experience of physical violence and of various forms of psychological violence (verbal abuse, bullying, sexual harassment, racial harassment, and threats) in the preceding year. Four interviewers were trained and certified in the administration of the questionnaire. The questionnaires were administered by verbal interview. The data were collected from April 2002 through June 2002.

\section{Statistical analyses}

Descriptive statistics were used to characterize the health staff's demographic characteristics. Univariate logistic regression analyses were employed to evaluate the association between individual demographic and workplace characteristics and exposures to physical violence and to psychological violence. Significant factors were subsequently modeled in multivariate logistic regression analyses to estimate the odds ratio (OR) of health staff experiencing the different types of violence. Confidence intervals (CIs) of the odds ratios are presented.

Statistical analyses were performed with SPSS version 12.0 software (SPSS Inc., Chicago, Illinois, United States of America). Statistical significance was defined as $P<0.05$.

\section{RESULTS}

Of the 958 persons who were eligible for the study, 832 subjects were enrolled. The participation rate (subjects enrolled/eligible approached) was thus $87 \%$.

\section{Health sector personnel characteristics}

The demographic characteristics of the health workers in the study are shown in Table 2. The sample consisted of 635 females $(76.3 \%)$ and 197 males $(23.7 \%)$. Almost $40 \%$ of staff were aged 34 years or less, and $11 \%$ were 55 years or older. Fifty-five percent of health workers reported they were either married or in common-law unions. Approximately one-fifth of the sample were from rural areas.

Table 3 shows that the large majority of the staff in the study worked in public hospitals $(n=576)$ and public health centers $(n=199)$; few persons in the sample were employed in private facilities $(n=57)$. These employment differences reflect the national health system. The largest professional group enrolled in the study were nurses $(24.2 \%), 22.5 \%$ of persons were employed in administrative or clerical positions, $16.7 \%$ were auxiliary/ancillary staff, and $13.6 \%$ of workers were categorized as support staff (e.g., maintenance staff). Almost $8 \%$ of persons were employed in professions allied to medicine, including medical technologists and radiographers. With the exception of physicians, who represented $5.0 \%$ of the sample, each of the remaining groups accounted for approximately $2 \%$ of the health personnel. Most persons $(74.0 \%)$ were employed in nonsupervisory staff positions.

The majority of the staff in the study $(89.4 \%)$ were full-time employees, and fewer than $1 \%$ of the subjects were on contracts (data not shown). Forty-four

TABLE 2. Demographic characteristics of health staff surveyed in study of physical and psychological violence in Jamaica's health sector, 2002

\begin{tabular}{lcc}
\hline \multicolumn{1}{c}{ Characteristic } & Number $^{\mathrm{a}}$ & Percent \\
\hline Gender & 197 & 23.7 \\
$\quad$ Males & 635 & 76.3 \\
$\quad$ Females & & \\
& & \\
Age groups (yr) & 66 & 8.0 \\
$\quad$ <25 & 259 & 31.5 \\
25-34 & 207 & 25.2 \\
35-44 & 202 & 24.5 \\
45-54 & 89 & 10.8 \\
55 and over & & \\
& & \\
Marital status & 373 & 45.2 \\
Single/Separated/Divorced & 453 & 54.8 \\
Married/Common-law & & \\
& & \\
Location of facility & 670 & 19.0 \\
$\quad$ Urban & 157 & \\
Rural & & \\
\hline Because of missing cases, not all categories total to 832. &
\end{tabular}

a Because of missing cases, not all categories total to 832 . 
TABLE 3. Number of subjects in study of physical and psychological violence in Jamaica's health sector, by type of health facility and category of employment, 2002

\begin{tabular}{|c|c|c|}
\hline & Number & Percent \\
\hline \multicolumn{3}{|l|}{ Type of facility } \\
\hline \multicolumn{3}{|l|}{ Public } \\
\hline Hospital & 576 & 69.2 \\
\hline Health center & 199 & 23.9 \\
\hline \multicolumn{3}{|l|}{ Private } \\
\hline Hospital & 32 & 3.8 \\
\hline Health center & 11 & 1.3 \\
\hline Medical center & 14 & 1.7 \\
\hline \multicolumn{3}{|l|}{ Professional group } \\
\hline Nurse & 201 & 24.2 \\
\hline Administrative/Clerical & 187 & 22.5 \\
\hline Auxiliary/Ancillary & 139 & 16.7 \\
\hline Support staff & 113 & 13.6 \\
\hline Profession allied to medicine & 62 & 7.5 \\
\hline Physician & 42 & 5.0 \\
\hline Midwife & 22 & 2.6 \\
\hline Technical staff & 16 & 1.9 \\
\hline Pharmacist & 15 & 1.8 \\
\hline Ambulance & 12 & 1.4 \\
\hline Other & 23 & 2.8 \\
\hline \multicolumn{3}{|l|}{ Positiona } \\
\hline Senior manager & 70 & 8.5 \\
\hline Supervisory/Line manager & 97 & 11.8 \\
\hline Nonsupervisory staff & 616 & 74.9 \\
\hline Student & 6 & 0.7 \\
\hline Independent & 15 & 1.8 \\
\hline Other & 18 & 2.2 \\
\hline
\end{tabular}

a 10 cases missing.

percent of the health staff had 1 to 10 years of work experience in the health sector, and $27 \%$ reported that they had joined the workforce 21 or more years ago. Forty-one percent of the staff worked on rotating shifts.

\section{Exposure to workplace violence}

Prevalence of violence. Subjects were asked about their exposure to each form of violence during the preceding year. Substantially more staff members had been exposed to psychological violence than to physical violence in the preceding year (Table 4). In terms of psychological violence, verbal abuse was more frequently reported $(38.6 \%)$ than was bullying $(12.4 \%)$. Just under $8 \%$ of the staff reported physical abuse, and it was somewhat more prevalent among males (9.7\%) than among females $(7.1 \%)$.

Physical violence. Health staff aged 44 years and younger were more likely to report physical violence than were older staff members (Table 4 ). The staff who were 55 and older reported the fewest incidents. Physical assaults were predominantly among persons attached to hospitals; the assaults were reported by approximately $10 \%$ of the hospital staff. Physicians, nurses, and ambulance staff were the categories of health professionals who reported the highest prevalence of physical violence.

There were considerable differences in terms of the work settings where physical violence occurred (data not shown). The largest proportions of hospital incidents took place in general medicine $(30 \%)$, psychiatric wards $(17 \%)$, administration units $(13 \%)$, and emergency units (11\%). There were no reports of physical violence among persons attached to technical services and intensive care units, perhaps due to those persons' having less contact with the public. Among nonhospital staff, almost $60 \%$ of incidents occurred at health centers, and $14 \%$ at long-term rehabilitation care centers.

Psychological violence. Verbal abuse was common, being indicated by $33 \%$ to $44 \%$ of the staff in the various age groups (Table 4). Verbal abuse tended to be somewhat higher among persons 34 years and younger than it was among older persons. The prevalence of verbal abuse was somewhat higher among health staff attached to health centers. Pharmacists, physicians, midwives, and nurses reported the highest occurrences of verbal abuse.

In comparison to verbal abuse, substantially fewer staff indicated they had been bullied, and with no clear pattern among the age groups (Table 4). Incidents of bullying tended to be reported more often by physicians and pharmacists.

Perpetrators of violence. Patients were the primary perpetrators of the physical and psychological violence (Table 4). The general public accounted for $8 \%$ of physical violence, $7 \%$ of the verbal abuse, and $9 \%$ of the bullying. Nonsupervisory staff members were perpetrators of considerable bullying and verbal abuse, and supervisors/managerial level staff were responsible for $12 \%$ of bullying.

The majority of physical assaults (79\%) were conducted without the use of a weapon (data not shown). However, when a weapon was used in an assault, men were more likely (37\%) than were women (14\%) to be assault victims. Almost all the acts of physical violence $(97 \%)$ and of psychological violence $(94 \%)$ took place inside health facilities; very few incidents took place on the way to work or on health visits outside the facilities. 
TABLE 4. Prevalence (\%) of physical violence and psychological violence in Jamaica's health sector, by gender and occupational characteristics and perpetrator of violence, 2002

\begin{tabular}{|c|c|c|c|}
\hline & \multirow{2}{*}{$\frac{\text { Physical }}{\text { Physical assault }}$} & \multicolumn{2}{|c|}{ Psychological } \\
\hline & & Verbal abuse & Bullying \\
\hline Overall prevalence & $7.7(64 / 831)$ & $38.6(321 / 832)$ & $12.4(103 / 832)$ \\
\hline \multicolumn{4}{|l|}{ Gender } \\
\hline Males $(n=197)$ & 9.4 & 36.5 & 13.2 \\
\hline Females $(n=635)$ & 7.1 & 39.2 & 12.1 \\
\hline \multicolumn{4}{|l|}{ Age group (yr) } \\
\hline$<25(n=66)$ & 9.1 & 42.4 & 13.6 \\
\hline $25-34(n=259)$ & 8.9 & 44.4 & 11.2 \\
\hline $35-44(n=207)$ & 10.2 & 37.2 & 14.5 \\
\hline $45-54(n=202)$ & 5.4 & 37.7 & 11.9 \\
\hline 55 and over $(n=89)$ & 2.2 & 32.6 & 10.1 \\
\hline \multicolumn{4}{|l|}{ Type of facility } \\
\hline Hospital $(n=608)$ & 9.7 & 37.2 & 11.8 \\
\hline Health center $(n=210)$ & 1.8 & 42.7 & 13.6 \\
\hline Medical center $(n=14)$ & 7.1 & 7.1 & 7.1 \\
\hline \multicolumn{4}{|l|}{ Occupational group affected } \\
\hline Nurse $(n=201)$ & 11.9 & 47.1 & 11.9 \\
\hline Administrative/Clerical $(n=187)$ & 5.2 & 40.9 & 11.4 \\
\hline Auxiliary/Ancillary $(n=139)$ & 7.6 & 27.4 & 8.5 \\
\hline Support staff $(n=113)$ & 7.6 & 28.6 & 14.3 \\
\hline Profession allied to medicine $(n=62)$ & 0 & 38.2 & 8.8 \\
\hline Physician $(n=42)$ & 18.6 & 51.2 & 30.2 \\
\hline Midwife $(n=22)$ & 6.1 & 48.5 & 18.2 \\
\hline Technical staff $(n=16)$ & 0 & 13.0 & 0 \\
\hline Pharmacist $(n=15)$ & 6.7 & 60.0 & 20.0 \\
\hline Ambulance $(n=12)$ & 16.7 & 25.0 & 16.7 \\
\hline Other $(n=23)$ & 0 & 20.5 & 8.3 \\
\hline \multicolumn{4}{|l|}{$\begin{array}{l}\text { Perpetrator of violence } \\
\text { (as \% of incidents) }\end{array}$} \\
\hline Patient/client & $68.8 \quad(44 / 64)$ & $57.9(186 / 321)$ & $42.2(43 / 102)$ \\
\hline Relatives of patients/clients & $17.2(11 / 64)$ & $14.0(45 / 321)$ & $8.8 \quad(9 / 102)$ \\
\hline Nonsupervisory staff member & $6.3 \quad(4 / 64)$ & $16.2(52 / 321)$ & $25.5(26 / 102)$ \\
\hline Supervisor/Management & $(0 / 64)$ & $4.0(13 / 321)$ & $11.8(12 / 102)$ \\
\hline External colleague/worker & $(0 / 64)$ & $0.9 \quad(3 / 321)$ & $2.9 \quad(3 / 102)$ \\
\hline General public & $(5 / 64)$ & $6.8 \quad(22 / 321)$ & (9/102) \\
\hline
\end{tabular}

Factors associated with physical and psychological violence. Univariate analyses showed reduced risk of physical violence among health staff who: were 55 years or older, worked at night (6:00 p.m. to 7:00 a.m.), or worked mostly with mentally disabled, geriatric, or HIV / AIDS patients (Table 5). In contrast, health staff members who were employed as a physician or as a nurse were at increased risk of physical violence. An increased risk of verbal abuse was found among physicians and nurses. Bullying was less common in those working with geriatric patients but was greater among physicians. Gender was not associated with either physical or psychological violence.

Multiple logistic regression analyses showed there was a reduced risk of physical violence for health staff who: were 55 years or older, worked nights, and worked mostly with mentally disabled, geriatric, or HIV / AIDS patients (Table 6). In contrast, working mostly with psychiatric patients increased the risks of physical assault. Nurses were more likely to be verbally abused than were other professional groups. An increased likelihood of being bullied was predicted among health staff $40-$ 54 years old, while caring mostly for mentally disabled patients reduced the risks of being bullied.

\section{DISCUSSION}

Our report describes patterns of physical and psychological violence experienced by health workers in a range of health care facilities representing the health system in Jamaica. The report also identifies risk factors associated with violence. The response rate was good, and representative samples of all categories of health staff were enrolled. Our data showed that psychological violence, in particular verbal abuse, was more prevalent than was physical violence, and that verbal abuse was evident throughout the health services. Disparate characteristics were associated with physical and psychological violence.

\section{Comparisons with other countries}

In recent years, studies in Jamaica looking at violence have focused on violence in schools (4-6) and on patientrelated injuries $(7,8)$. However, to date there have been no other studies published on workplace violence in the health sector. Hence, data on the prevalence of health sector workplace violence over time is unknown, and trends cannot be described.

We compared the prevalence of physical and psychological violence in the health sector in Jamaica with the patterns in the other countries participating in the ILO/ICN/WHO/PSI joint initiative study. The prevalence of physical violence in Jamaica $(7.7 \%)$ was higher than in Lebanon $(5.8 \%)$, Brazil (6.4\%), and Bulgaria (7.5\%), but lower than in Thailand (10.5\%) and South Africa (private sector, 9\%; public sector, 17\%) (3). 
TABLE 5. Factors associated with physical and psychological violence in Jamaica's health sector, 2002, according to univariate analysis, with odds ratios (ORs) and $95 \%$ confidence intervals (Cls)

\begin{tabular}{|c|c|c|c|c|c|c|}
\hline \multirow[b]{2}{*}{ Risk factor } & \multicolumn{2}{|c|}{ Physical assault } & \multicolumn{2}{|c|}{ Verbal abuse } & \multicolumn{2}{|c|}{ Bullying } \\
\hline & OR & $95 \% \mathrm{Cl}$ & OR & $95 \% \mathrm{Cl}$ & OR & $95 \% \mathrm{Cl}$ \\
\hline \multicolumn{7}{|l|}{ Gender } \\
\hline Males & 1.0 & - & 1.0 & - & 1.0 & - \\
\hline Females & 0.71 & $0.40-1.25$ & 1.12 & $0.80-1.56$ & 0.91 & $0.56-4.46$ \\
\hline Age $<40$ years & 1.0 & - & 1.0 & - & 1.0 & - \\
\hline 40-54 years & 0.34 & $0.77-2.31$ & 0.68 & $0.50-0.92$ & 1.20 & $0.77-1.86$ \\
\hline$\geq 55$ years & 0.40 & $0.01-0.57$ & 0.64 & $0.40-1.04$ & 0.85 & $0.40-1.79$ \\
\hline \multicolumn{7}{|l|}{ Work 6:00 p.m.-7:00 a.m. } \\
\hline No & 1.0 & - & 1.0 & - & 1.0 & - \\
\hline Yes & 0.31 & $0.17-0.55$ & 0.42 & $0.26-1.77$ & 0.77 & $0.51-1.17$ \\
\hline \multicolumn{7}{|l|}{$\begin{array}{l}\text { Work mostly with mentally } \\
\text { disabled patients }\end{array}$} \\
\hline No & 1.0 & - & 1.0 & - & 1.0 & - \\
\hline Yes & 0.32 & $0.10-0.97$ & 0.58 & $0.25-1.31$ & 0.19 & $0.07-1.50$ \\
\hline \multicolumn{7}{|l|}{$\begin{array}{l}\text { Work mostly with geriatric } \\
\text { patients }\end{array}$} \\
\hline No & 1.0 & - & 1.0 & - & 1.0 & - \\
\hline Yes & 0.38 & $0.16-0.89$ & 0.58 & $0.33-1.02$ & 0.41 & $0.20-0.87$ \\
\hline \multicolumn{7}{|l|}{$\begin{array}{l}\text { Work mostly with } \\
\text { psychiatric patients }\end{array}$} \\
\hline No & 1.0 & - & 1.0 & - & 1.0 & - \\
\hline Yes & 2.58 & $1.16-5.74$ & 1.09 & $0.54-1.61$ & 0.88 & $0.33-2.05$ \\
\hline \multicolumn{7}{|l|}{$\begin{array}{l}\text { Work mostly with } \\
\text { HIV/AIDS patients }\end{array}$} \\
\hline No & 1.0 & - & 1.0 & - & 1.0 & - \\
\hline Yes & 0.28 & $0.22-0.99$ & 0.87 & $0.52-1.48$ & 0.78 & $0.37-1.63$ \\
\hline \multicolumn{7}{|l|}{ Professional group: } \\
\hline \multicolumn{7}{|l|}{ Technical staff/ } \\
\hline Pharmacist/Other & 1.0 & - & 1.0 & - & 1.0 & - \\
\hline Physician & 13.94 & $1.67-38.15$ & 2.77 & $1.22-6.28$ & 4.94 & $1.61-15.18$ \\
\hline Nurse & 7.62 & $1.01-27.34$ & 2.38 & $1.29-4.39$ & 1.67 & $0.62-4.48$ \\
\hline Auxiliary/Ancillary & 5.03 & $0.61-21.85$ & 1.10 & $0.49-2.01$ & 1.06 & $0.34-3.31$ \\
\hline Administrative/Clerical & 3.33 & $0.58-26.94$ & 1.83 & $0.97-3.43$ & 1.47 & $0.53-4.05$ \\
\hline
\end{tabular}

The magnitude of verbal abuse in Jamaica (38.6\%) was greater than in Bulgaria $(32 \%)$, but lower than in Brazil (39.5\%), Lebanon (41\%), Thailand $(48 \%)$, South Africa (52\%), and Australia (67\%) (3).

The rates of bullying were lower in Thailand (10.7\%) and Australia (10.5\%) than in Jamaica (12.4\%), but they were higher in Brazil (15.2\%), South Africa $(20.6 \%)$, Lebanon $(22.1 \%)$, and especially Bulgaria (30.9\%) (3).

Irrespective of how Jamaica's rates of health-sector workplace violence compare with rates in other countries, the occurrence of such levels of aggression in Jamaica is of concern in view of the psychological effects of violence. Our findings of widespread workplace violence against health personnel in Jamaica also underscore the worldwide importance of violence in the health sector (3).

\section{Physical violence}

In the Jamaica health sector, professionals such as nurses, physicians, and administrative/clerical employees who were more likely to have frequent contact with patients were more likely to report exposures to physical violence. In contrast, few or no physical assaults were reported by groups such as pharmacists, professions allied to medicine, or technical staff. Staff working primarily with psychiatric patients had four times the risk of physical assault that other staff did. A similar pattern has been documented for health care workers in other countries (9-13).

It is noteworthy that a considerable percentage of the health staff in Jamaica who had experienced some form of physical or psychological violence considered it an inevitable part of the job. This belief was held by 55\% of those who had experienced physical assault, $80 \%$ of those who had experienced verbal abuse, and $77 \%$ of those who had experienced bullying. Because of their frequent contact with violence in the workplace, many health staff may have come to accept that situation as being "normal."

The International Labour Office reports that violence against health personnel is widespread internationally, including in Jamaica and other countries that are undergoing an economic transition (14). However, Koop and Lundberg (15) believe that health workers should not have to accept occupational violence as part of the job. Those two authors emphasize that employees should be trained to assess and manage situations that may escalate into violence.

\section{Psychological violence}

Our study in Jamaica found that psychological violence was widespread in the health sector. For example, of the 11 occupational groups that we studied, all of them reported verbal abuse, and all but one of them reported bullying. The findings of higher rates of psychological violence among physicians and pharmacists may be due to the long waiting periods for services that patients experience. In addition, patients who display an acute confusional state secondary to a physical 
TABLE 6. Factors associated with physical and psychological violence in Jamaica's health sector, 2002, according to multiple logistic regression analysis, with odds ratios (ORs) and $95 \%$ confidence intervals (Cls)

\begin{tabular}{|c|c|c|c|c|c|c|}
\hline \multirow[b]{2}{*}{ Risk factor } & \multicolumn{2}{|c|}{ Physical assault } & \multicolumn{2}{|c|}{ Verbal abuse } & \multicolumn{2}{|c|}{ Bullying } \\
\hline & OR & $95 \% \mathrm{Cl}$ & OR & $95 \% \mathrm{Cl}$ & OR & $95 \% \mathrm{Cl}$ \\
\hline Age $<40$ years & 1.0 & - & 1.0 & - & 1.0 & - \\
\hline 40-54 years & 0.39 & $0.77-2.31$ & 0.79 & $0.49-1.26$ & 1.96 & $1.01-3.94$ \\
\hline$\geq 55$ years & 0.11 & $0.01-0.57$ & 0.50 & $0.24-1.04$ & 0.59 & $0.15-2.32$ \\
\hline \multicolumn{7}{|l|}{ Work 6:00 p.m.-7:00 a.m. } \\
\hline No & 1.0 & - & 1.0 & - & 1.0 & - \\
\hline Yes & 0.25 & $0.17-0.55$ & 0.94 & $0.58-1.51$ & 1.00 & $0.47-2.11$ \\
\hline \multicolumn{7}{|l|}{$\begin{array}{l}\text { Work mostly with mentally } \\
\text { disabled patients }\end{array}$} \\
\hline No & 1.0 & - & 1.0 & - & 1.0 & - \\
\hline Yes & 0.18 & $0.10-0.97$ & 0.49 & $0.17-1.40$ & 0.08 & $0.02-0.24$ \\
\hline \multicolumn{7}{|l|}{$\begin{array}{l}\text { Work mostly with geriatric } \\
\text { patients }\end{array}$} \\
\hline No & 1.0 & - & 1.0 & - & 1.0 & - \\
\hline Yes & 0.53 & $0.16-0.89$ & 0.63 & $0.33-1.18$ & 0.45 & $0.19-1.05$ \\
\hline \multicolumn{7}{|l|}{$\begin{array}{l}\text { Work mostly with } \\
\text { psychiatric patients }\end{array}$} \\
\hline No & 1.0 & - & 1.0 & - & 1.0 & - \\
\hline Yes & 4.30 & $1.16-5.74$ & 1.23 & $0.59-2.52$ & 1.88 & $0.60-5.90$ \\
\hline \multicolumn{7}{|l|}{ Work mostly with } \\
\hline \multicolumn{7}{|l|}{ HIV/AIDS patients } \\
\hline No & 1.0 & - & 1.0 & - & 1.0 & - \\
\hline Yes & 0.19 & $0.22-0.99$ & 0.83 & $0.43-1.57$ & 0.68 & $0.25-1.91$ \\
\hline \multicolumn{7}{|l|}{ Professional group: } \\
\hline \multicolumn{7}{|l|}{ Technical staff/ } \\
\hline Pharmacist/Other & 1.0 & - & 1.0 & - & 1.0 & - \\
\hline Physician & 5.75 & $0.59-26.21$ & 2.09 & $0.76-5.78$ & 3.31 & $0.74-14.77$ \\
\hline Nurse & 2.41 & $0.29-20.31$ & 2.33 & $1.02-5.32$ & 1.70 & $0.44-6.55$ \\
\hline Auxiliary/Ancillary & 0.53 & $0.42-6.85$ & 0.95 & $0.37-2.43$ & 0.69 & $0.14-3.48$ \\
\hline Administrative/Clerical & 3.56 & $0.36-23.94$ & 2.13 & $0.79-5.74$ & 0.91 & $0.15-5.41$ \\
\hline
\end{tabular}

condition are likely to verbally abuse physicians and nurses

Violence in the health sector workplace in Jamaica and in other countries can be viewed as a public health issue that merits examination of risk factors and interventions (16). According to the World Health Organization, violence in society in general is both predictable and preventable, and much can be achieved with a variety of interventions (17). Lee et al. (9) suggest that health workplace violence often results from poor working conditions and inadequate design and layout of facilities (9). We did not find in Jamaica that measures to deal with any form of violence (e.g., enforcement of security measures, restriction on public access) or that specific policies relating to workplace physical violence and verbal abuse were either protective against or predictive of any of the violent outcomes studied. It is likely that traditional approaches to violence in the workplace that are based exclusively on the enforcement of regulations have failed to be effective in the health sector workplace in Jamaica.

Physical injuries and abusive or threatening incidents in the health workplace can result in serious and disabling psychological damage, including posttraumatic stress disorder; depression; irritability; disturbed relationships with family, friends, and coworkers; decreased ability to function at work; and increased absenteeism. Furthermore, workers often blame themselves for injuries resulting from physical violence, and management often encourages this self-blame (18). Timely interventions are needed in Jamaica in view of the psychological effects on individuals.

\section{CONCLUSION}

Our data from Jamaica corroborate other findings that violence in the health sector workplace is an occupational hazard and is of public health concern. Evaluation of the environment that creates the risk of violence for health staff members is needed in order to guide the formulation of meaningful interventions.

\section{REFERENCES}

1. Heath I. Treating violence as a public health problem. Br Med J. 2002;325:726-7.

2. McDonald A, Duncan ND, Mitchell DI, Fletcher PR. Trauma aetiology and cost in the Accident and Emergency Unit of the University Hospital of the West Indies. West Indian Med J. 1999;48(3):141-2.

3. Di Martino V. Workplace violence in the health sector. Country case studies. Brazil, Bulgaria, Lebanon, Portugal, South Africa,
Thailand and an additional Australian study. Geneva: International Labour Office, International Council of Nurses, World Health Organization, and Public Services International; 2002.

4. Fernald L, Ani C, Gardener JM. Aggressive behaviour in children and adolescents. Part I: a review of the effects of child and family characteristics. West Indian Med J. 1997;46(4): 100-3.
5. Soyibo L, Lee MG. Domestic and school violence among high school students in Jamaica. West Indian Med J. 2000;49(3):232-6.

6. Gardener JM, Powell CA, Thomas JA, Millard D. Perceptions and experiences of violence among secondary school students in urban Jamaica. Rev Panam Salud Publica. 2003;14(2): 97-103.

7. Zohoori N, Ward E, Gordon G, Wilks R, Ashley D, Forrester T. Non-fatal violence-related 
injuries in Kingston, Jamaica: a preventable drain on resources. Inj Control Saf Promot. 2002;9(4):255-62.

8. Hasbrouck LM, Durant T, Ward E, Gordon G. Surveillance of interpersonal violence in Kingston, Jamaica: an evaluation. Inj Control Saf Promot. 2002;9(4):249-53.

9. Lee SS, Gerberich SG, Waller LA, Anderson A, McGovern P. Work-related assault injuries among nurses. Epidemiology. 1999;10(6): 685-91.

10. Flannery RB, Fisher W, Walker AP, Littlewood KB, Spillane MJ. Non-violent psychiatric inpatients and subsequent assaults on community patients and staff. Psychiatr Q. 2001;72(1):19-27.
11. MacHale S. Violence in the workplace. Delirium should be considered [letter]. Br Med J. 2002;324:788

12. Tuddenham LM. Violence in the workplace. Mentally ill patients are responsible for their actions [letter]. Br Med J. 2002;324:788.

13. Jones C. Violence in the workplace. Zero tolerance is not helpful in mental health [letter]. Br Med J. 2002;324:789.

14. International Labour Organization. Violence and stress at the workplace. Available from: http://www.ILO-mirror.cornell.edu [Web site]. Accessed 15 November 2004

15. Koop CE, Lundberg GD. Violence in America: a public health emergency: time to bite the bullet [editorial]. JAMA. 1992;267:3075-6.
16. Koplan JP, Fleming DW. Current and future public health challenge. JAMA. 2000;248(13): 1696-8.

17. World Health Organization. Violence: a public health priority. Geneva: WHO; 1996.

18. Krug EG, Dahlberg LL, Mercy JA, Zwi AB, Lozano R, eds. World report on violence and health. Geneva: World Health Organization; 2002.

Manuscript received 30 November 2004. Accepted for publication 22 April 2005.

RESUMEN Objetivo. Determinar la prevalencia de experiencias con episodios de violencia física y psicológica en el lugar de trabajo entre miembros del personal de salud de Jamaica, así como los factores que se asocian con dichas experiencias.

La violencia física y psicológica en el sector de la salud en Jamaica

Palabras clave
Métodos. Un total de 832 miembros del personal de salud de plantilla respondieron al cuestionario estandarizado que se usó en este estudio transversal. La muestra se obtuvo en instalaciones públicas, entre ellas hospitales especializados, terciarios y secundarios de la zona metropolitana de Kingston; hospitales generales en las parroquias rurales; y centros de atención primaria de salud en zonas urbanas y rurales. También se hizo un muestreo en hospitales y centros médicos privados.

Resultados. La violencia psicológica fue más frecuente que la física. Durante el año anterior a la encuesta, 38,6\% de los encuestados habían sido víctimas de abuso verbal; 12,4\%, de acoso, y 7,7\% de maltrato físico. En análisis multifactoriales se observó un menor riesgo de sufrir violencia física entre miembros del personal de salud que tenían 55 años de edad o más, que trabajaban de noche, o que trabajaban principalmente con pacientes mentalmente discapacitados, pacientes geriátricos, o pacientes con infección por VIH o sida. En los miembros del personal que trabajaban principalmente con pacientes psiquiátricos se detectó un mayor riesgo de sufrir ataques físicos que en otros trabajadores de la salud. De las diversas ocupaciones pertenecientes al ámbito de la salud, la de enfermería fue en la que más se halló la propensión a ser víctima de abuso verbal. En cuanto a grupos de edad, el acoso se observó con más frecuencia en trabajadores de salud entre las edades de 40 y 54 años.

Conclusiones. La violencia en el lugar de trabajo en Jamaica es un peligro ocupacional que merece la atención del sector sanitario. Es necesario evaluar el tipo de ambiente que propicia la violencia a fin de formular intervenciones eficaces en el país.

Lugar de trabajo, personal de salud, violencia, heridas y traumatismos, estrés psicológico, salud ocupacional, Jamaica. 